No. 11(18)

\title{
WAVELETS IN THE PREDICTION OF SHORT-TIME SERIES
}

\author{
Monika Hadaś-Dyduch
}

\begin{abstract}
The aim of this article is to present original application wavelets to the prediction of short-term of time series. The model proposed to predict short-term time series (in particular for predicting macroeconomic indicators) is a model of copyright. The model is based on wavelet analysis, the Haar wavelet, the Daubechies wavelet and adaptive models. The Daubechies wavelets are a family of orthogonal wavelets and are characterized by a maximal number of vanishing moments for some given support. Adaptive models have been appropriately modified by the introduction of a wavelet function and combined into one predictive model. The results obtained from the study results indicate that the authorial model is an effective tool for short-term predictions. The model was applied to predict macroeconomic indicators.
\end{abstract}

Keywords: wavelets, prediction, Daubechies wavelets, Haar wavelet.

JEL Classification: A10, C15, C23.

DOI: $10.15611 /$ me.2015.11.04.

\section{Introduction}

The prediction of time series is the subject of research of many scientists and scientific teams (see also: [Albulescu 2010; Andreica 2006; Dyduch 2011; Hadaś-Dyduch 2013b; Joo, Kim 2015]). However, by reviewing the literature it was noted that adaptive methods are a tool used in forecasting many macroeconomic indicators. An important advantage is simplicity, relatively simple algorithm of use and ease of understanding and interpreting the results. It can be argued that adaptive methods are useful prognostic tools. Therefore, the studies described below, in order to obtain the smaller prediction error, are combined with a method adaptive wavelet analysis.

The described algorithm to predict short-time series is the copyright algorithm. Combining the aim of smoothing the time series with the wavelet analysis method creeping trend, creates authorial trend of creepy-wavelet. In

\footnotetext{
Monika Hadaś-Dyduch

Department of Statistical and Mathematical Methods in Economics, University of Economics in Katowice

monika.dyduch@ue.katowice.pl
} 
addition, the trend obtained from a series of creepy-wavelet method was applied to compensate for exponential, creating an original method of exponentially-wavelet.

Research shows [Bruzda 2004; Dyduch 2010a, 2010b, 2010c, 2013; Hadaś-Dyduch 2013a, 2013b, 2013d, 2014a, 2014b, 2015a, 2015b, 2015c; Horodko 2001; Joo, Kim 2015] that wavelet analysis can be used on a variety of academic levels, among other things: to study the properties of economic processes, smoothing ranks, removing noise, study the relationship between the processes of different time scales and so on.

In this article we used wavelets to forecast time series. Based on the properties of wavelets, the constructed algorithm combines the adaptive method of wavelet analysis. This created original trend creepy-wavelet and model alignment exponentially-wavelet. By combining trend creepywavelet with model alignment exponentially-wavelet, the algorithm for prediction of short-term time series was created. The study included only Daubechies wavelet.

\section{Wavelet analysis}

"From an historical point of view, wavelet analysis is a new method, though its mathematical underpinnings date back to the work of Joseph Fourier in the nineteenth century. Fourier laid the foundations with his theories of frequency analysis, which proved to be enormously important and influential. The attention of researchers gradually turned from frequency-based analysis to scale-based analysis when it started to become clear that an approach measuring average fluctuations at different scales might prove less sensitive to noise. The first recorded mention of what we now call a 'wavelet' seems to be in 1909, in a thesis by Alfred Haar. The concept of wavelets in its present theoretical form was first proposed by Jean Morlet and the team at the Marseille Theoretical Physics Center working under Alex Grossmann in France. The methods of wavelet analysis have been developed mainly by Y. Meyer and his colleagues, who have ensured the methods' dissemination. The main algorithm dates back to the work of Stephane Mallat in 1988. Since then, research on wavelets has become international. Such research is particularly active in the United States, where it is spearheaded by the work of scientists such as Ingrid Daubechies, Ronald Coifman, and Victor Wickerhauser” (Wavelet Toolbox, Matlab). 
Definition 1. Wavelets we call function $\Psi(x) \in L^{2}(\mathbb{R})$, such that the system functions:

$$
B_{\Psi}=\left\{2^{\frac{j}{2}} \Psi\left(2^{j} x-k\right)\right\} ; \quad j \in \mathbb{Z}, \quad k \in \mathbb{Z}
$$

is an orthonormal basis in the space $L^{2}(R)$. Family $B_{\Psi}$ will be called wavelet base.

The simplest wavelet is the Haar wavelet. “(...) In mathematics, the Haar wavelet is a sequence of rescaled 'square-shaped' functions which together form a wavelet family or basis. Wavelet analysis is similar to Fourier analysis in that it allows a target function over an interval to be represented in terms of an orthonormal function basis. The Haar sequence is now recognised as the first known wavelet basis and extensively used as a teaching example (...)” [Hadaś-Dyduch 2015c].

The Haar sequence was proposed in 1909 by Alfréd Haar. Haar used these functions to give an example of an orthonormal system for the space of square-integrable functions on the unit interval $[0,1]$. The study of wavelets, and even the term "wavelet", did not come until much later. As a special case of the Daubechies wavelet, the Haar wavelet is also known as D2 [Haar 1910].

Definition 2. Haar wavelets we call a function on the real line $\mathbb{R}$ defined by the formula:

$$
H(x)=\left\{\begin{array}{rll}
1 & \text { for } & x \in\left[0, \frac{1}{2}\right) \\
-1 & \text { for } & {\left[\frac{1}{2}, 1\right)} \\
0 & \text { for } & \text { other } x
\end{array} .\right.
$$

Daubechies' wavelets first row (db1) is the Haar wavelets (Daubechies wavelets are wavelets created by Ingrid Daubechies6 in 1988).

Each wavelet has a number of zero moments or vanishing moments equal to half the number of coefficients. For example, D2 (the Haar wavelet) has one vanishing moment, D4 has two, etc. A vanishing moment limits the wavelets ability to represent polynomial behaviour or information in a signal. For example, D2, with one moment, easily encodes polynomials of one coefficient, or constant signal components. D4 encodes polynomials with two coefficients, i.e. constant and linear signal components; and D6 
encodes 3-polynomials, i.e. constant, linear and quadratic signal components. This ability to encode signals is nonetheless subject to the phenomenon of scale leakage, and the lack of shift-invariance, which arises from the discrete shifting operation (below) during the application of the transform Sub-sequences which represent linear, quadratic (for example) signal components are treated differently by the transform depending on whether the points align with even or odd-numbered locations in the sequence. The lack of the important property of shift-invariance has led to the development of several different versions of a shift-invariant (discrete) wavelet transform (see: [Daubechies 1990]).

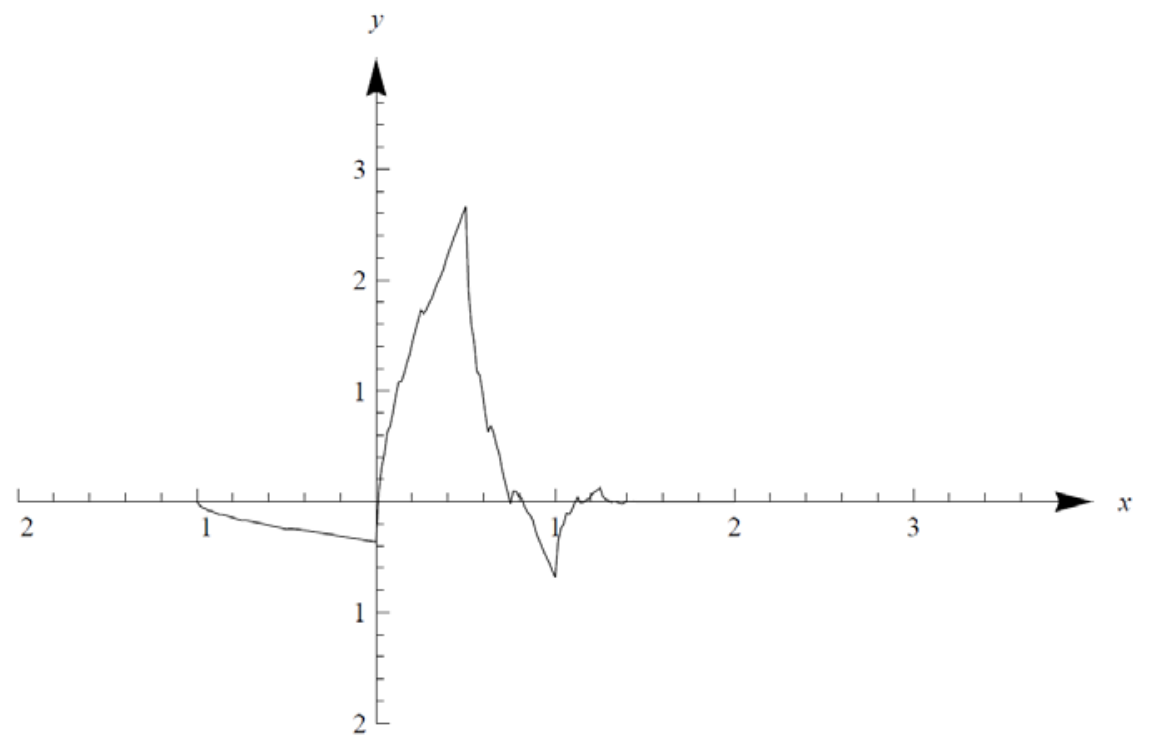

Fig. 1. Daubechies wavelets

Source: own elaboration.

"In contrast to Haar's simple-step wavelets, which exhibit jump discontinuities, Daubechies wavelets are continuous. As a consequence of their continuity, Daubechies wavelets approximate continuous signal more accurately with fewer wavelets than do Harr's wavelets, but at the cost of intricate algorithms based upon a sophisticated theory. The Daubechies wavelets, are a family of orthogonal wavelets and characterized by a maximal number of vanishing moments for some given support. With each wavelet type of this class, there is a scaling function which generates an orthogonal multi-resolution analysis. Furthermore, each Daubechies wavelet is com- 
pactly supported. The Daubechies wavelets are neither symmetric nor antisymmetric around any axis, except for $\mathrm{db} 1$, which is in fact the Haar wavelet. Satisfying symmetry conditions cannot go together with all other properties of the Daubechies wavelets” [Daubechies 1990].

\section{Models - methodology}

The model described in this article is a model copyright for time series prediction. The model is intended for prediction under one time series. It is designed to predict short-term. The proposed model is based on wavelet analysis (with Daubechies wavelets) and adaptive models, i.e. an alignment exponential model and creeping trend model. The model consists of several key steps.

Step 1. To model the input we introduce time series $y_{1}, y_{2}, \ldots, y_{n}$, one-dimensional, $n$-element.

Step 2. We determine an arbitrarily value of smoothing constant $l$, then we determine the sub-series of length $l$, i.e.:

$$
y_{1}, y_{2}, \ldots, y_{l} ; y_{2}, y_{3}, \ldots, y_{l+1}, y_{3}, y_{4}, \ldots, y_{l+2}, \ldots
$$

Sub-series formed from the series $y_{1}, y_{2}, \ldots, y_{n}$. The number of sub-series (i.e. models segment) that can be created from the time series $Y$ for a selected length of $l$ is $n-l-1$, where: $k$ - the number of models segment, $l-\mathrm{s}$ constant smoothing.

Step 3. In each model segment, we are expanding the polynomial method or another alternative method. For this purpose, input series $Y$ we have written as:

$$
S_{0}, S_{1}, S_{2}, \cdots, S_{2^{n}-2}, S_{2^{n}-1} .
$$

The main extension number of data, using polynomial method, can be written as follows:

$$
s_{2^{n}}, \cdots, s_{2^{n+1}-1},
$$

a short extension, we save as a copy of the first two series of input elements, i.e.:

$$
s_{0}, s_{1} \text {. }
$$

Thus we obtain a new series, extended relative towards the input series:

$$
s_{0}, s_{1}, s_{2}, \cdots, s_{2^{n}-2}, s_{2^{n}-1} s_{2^{n}}, \cdots, s_{2^{n+1}-1} s_{0}, s_{1} .
$$


To move to the next stage we should determine the missing elements of series (3).

Assuming that:

$$
s_{0}-s_{2^{n+1}-1}=s_{1}-s_{0},
$$

obtain the equation from which one can designate the last element of the main extension of the series:

$$
s_{2^{n+1}-1}=2 s_{0}-s_{1} .
$$

From the polynomial [Nievergelt 1999]:

$$
\begin{aligned}
p(r)= & p_{0}+p_{1}\left(r-\left[2^{n}-1\right]\right)+p_{2}\left(r-\left[2^{n}-1\right]\right)\left(r-\left[2^{n}\right]\right)+ \\
& p_{3}\left(r-\left[2^{n}-1\right]\right)\left(r-\left[2^{n}\right]\right)\left(r-\left[2^{n+1}-1\right]\right)
\end{aligned}
$$

with conditions:

$$
\begin{gathered}
p\left(2^{n}-1\right)=s_{2^{n}-1}, \\
p\left(2^{n}\right)=s_{2^{n}}, \\
p\left(2^{n}\right)=2 s_{2^{n}-1}-s_{2^{n}-2}, \\
p\left(2^{n+1}-1\right)=s_{2^{n+1}-1}, \\
p\left(2^{n+1}-1\right)=2 s_{0}-s_{1}, \\
p\left(2^{n+1}\right)=s_{0}
\end{gathered}
$$

we have:

$$
\begin{gathered}
p_{0}=s_{2^{n}-1}, \\
p_{1}=s_{2^{n}-1}-s_{2^{n}-2}, \\
p_{2}=\frac{2 s_{0}-s_{1}-s_{2^{n}-1}-2^{n} p_{1}}{2^{n}\left(2^{n}-1\right)}, \\
p_{2}=\frac{s_{0}-s_{2^{n}-1}-\left(2^{n}+1\right) p_{1}}{2^{n}\left(2^{n}+1\right)}-p_{2} .
\end{gathered}
$$

Thus:

$$
s_{k}:=p(k), k \in\left[2^{n}+1,2^{n+1}-2\right] .
$$

The extracted from series sub-series length $l$ can be extended by using other alternative provisions and methods. For example: 


$$
\underbrace{p_{2^{n}-1}, \cdots, p_{0}}_{\text {extended }}, \underbrace{p_{0}, p_{1}, p_{2}, \cdots, p_{2^{n}-2}, p_{2^{n}-1}}_{\text {series }}, \underbrace{p_{2^{n}-1}, \cdots, p_{0}}_{\text {extended }}
$$

or:

$$
\underbrace{p_{0}, p_{1}, p_{2}, \cdots, p_{2^{n}-2}, p_{2^{n}-1}}_{\text {extended }}, \underbrace{p_{0}, p_{1}, p_{2}, \cdots, p_{2^{n}-2}, p_{2^{n}-1}}_{\text {series }}, \underbrace{p_{0}, p_{1}, p_{2}, \cdots, p_{2^{n}-2}, p_{2^{n}-1}}_{\text {extended }} .
$$

Step 4. In the classical method of creeping trend, they are determined for each sub-series linear function of the trend. In the proposed approach, they are determined for each segment of the extended model approximating wavelet functions. Approximating function is:

$$
\tilde{f}(r)=\sum_{k=0}^{2^{n}-1} a_{k}^{(n-1)} \cdot \varphi([r / 2]-k)+\sum_{k=0}^{2^{n}-1} c_{k}^{(n-1)} \cdot \psi([r / 2-1]-k),
$$

where:

$$
\begin{aligned}
& \psi(r)=-\frac{1+\sqrt{3}}{4} \varphi(2 r-1)+\frac{3+\sqrt{3}}{4} \varphi(2 r)-\frac{3-\sqrt{3}}{4} \varphi(2 r+1)+\frac{1-\sqrt{3}}{4} \varphi(2 r+2) \\
& \psi(r)=0 \text { for } r<-1 \text { or } r>2, \\
& \varphi(r)=\frac{1+\sqrt{3}}{4} \varphi(2 r)+\frac{3+\sqrt{3}}{4} \varphi(2 r-1)+\frac{3-\sqrt{3}}{4} \varphi(2 r-2)+\frac{1-\sqrt{3}}{4} \varphi(2 r-3) \\
& \sum_{k \in Z} \varphi(k)=1, \\
& \varphi(r)=0 \text { for } r \leq 0 \vee r \geq 3, D_{j}=\left\{k 2^{j}: k \in Z\right\}, D=\bigcup_{j \in Z} D_{j}=\bigcup_{j=0}^{\infty} D_{j} .
\end{aligned}
$$

For $l=4$ function (17) we have written as follows:

for one level of resolution:

$$
\begin{aligned}
\tilde{f}(r)= & a_{0}^{(n-1)} \cdot \varphi([r / 2])+a_{1}^{(n-1)} \cdot \varphi([r / 2]-2)+a_{2}^{(n-1)} \cdot \varphi([r / 2]-4)+ \\
& a_{3}^{(n-1)} \cdot \varphi([r / 2]-6)+c_{0}^{(n-1)} \cdot \psi([r / 2-1])+c_{1}^{(n-1)} \cdot \psi([r / 2-1]-2)+ \\
& c_{2}^{(n-1)} \cdot \psi([r / 2-1]-4)+c_{3}^{(n-1)} \cdot \psi([r / 2-1]-6)
\end{aligned}
$$

for two levels of resolution:

$$
\begin{aligned}
\tilde{f}(r)= & a_{0}^{(n-2)} \cdot \varphi([r / 4])+a_{1}^{(n-2)} \cdot \varphi([r / 4]-4)+c_{0}^{(n-2)} \cdot \psi([r / 4-1])+ \\
& c_{1}^{(n-2)} \cdot \psi([r / 4-1]-4)+c_{0}^{(n-1)} \cdot \psi([r / 2-1])+c_{1}^{(n-1)} \cdot \psi([r / 2-1]-2)+ \\
& c_{2}^{(n-1)} \cdot \psi([r / 2-1]-4)+c_{3}^{(n-1)} \cdot \psi([r / 2-1]-6) ;
\end{aligned}
$$


for three levels of resolution:

$$
\begin{aligned}
\tilde{f}(r)= & a_{0}^{(n-3)} \cdot \varphi([r / 8])+c_{0}^{(n-3)} \cdot \psi([r / 8-1])+c_{0}^{(n-2)} \cdot \psi([r / 4-1])+ \\
& c_{1}^{(n-2)} \cdot \psi([r / 4-1]-4)+c_{0}^{(n-1)} \cdot \psi([r / 2-1])+c_{1}^{(n-1)} \cdot \psi([r / 2-1]-2)+ \\
& c_{2}^{(n-1)} \cdot \psi([r / 2-1]-4)+c_{3}^{(n-1)} \cdot \psi([r / 2-1]-6) .
\end{aligned}
$$

According to the algorithm method, creeping trend determines the theoretical values of variable $Y$ in the individual segments. However, at this stage, this is a modification in relation to the classical method creeping trend.

The theoretical values of approximating function, described by equation (17),are determined in each segment for $r=0,1,2,3, \cdots, m+1$, where $m$ is the number of elements in the segment.

From the set of theoretical values for a specific year, we calculate the arithmetic mean. As a result, we obtain theoretical values variable $Y$. The received theoretical values of $Y$, we denoted as $\hat{Y}$.

Step 5. Determine the forecast for one period forward by the formula:

$$
\hat{\hat{y}}_{t+1}^{P}=\alpha \cdot \hat{y}_{t+1}+(1-\alpha) \cdot y_{t},
$$

wherein $\hat{y}_{t+1}$ represents the value of the smoothed by the trend creepywavelet, obtained in step 4 .

Parameter $\alpha \in[0,1]$, called the smoothing constant, selected so as to minimize errors forecast ex-post.

\section{Data, empirical result}

Implementation of the author's model, described in detail in Chapter 2, presents the number of unemployed in eurozone countries. The time series included in the study is the period 1997-2014 ((EA11-2000, EA12-2006, EA13-2007, EA15-2008, EA16-2010, EA17-2013, EA18-2014, EA19), the annual average, 1,000 people). Data on the number of unemployed was taken from the Eurostat database.

For applications algorithms described in Chapter 2, we accept: $l=4$ and one level of resolution wavelets. Thus, the theoretical values in the general form are as follows: 


$$
\begin{array}{llll}
\frac{1}{l+r-3} \sum_{i=1}^{l+r-3} \tilde{f}_{i}(r), & \text { for } & r=0,1,2,3,4------------\rightarrow \hat{y}_{1}, \hat{y}_{2}, \hat{y}_{3}, \hat{y}_{4}, \hat{y}_{5}, \\
\frac{1}{l+1} \sum_{i=2+r}^{l+r+2} \tilde{f}_{i}(r), & \text { for } \quad r=0,1,2,3,4-----------\rightarrow \hat{y}_{6}, \hat{y}_{7}, \hat{y}_{8}, \hat{y}_{9}, \hat{y}_{10}, \\
\frac{1}{l+1} \sum_{i=7+r}^{r+7} \tilde{f}_{i}(r), & \text { for } \quad r=0,1,2,3 \quad-----------\rightarrow \hat{y}_{11}, \hat{y}_{12}, \hat{y}_{13}, \hat{y}_{14}, \\
\frac{1}{l} \sum_{i=l+6}^{l+10} \tilde{f}_{i}(r), & \text { for } \quad r=4 & - \\
\frac{1}{l-r-1} \sum_{i=l+8+r}^{l+10} \tilde{f}_{i}(r), & \text { for } \quad r=0,1,2 & -------------\rightarrow \hat{y}_{15},
\end{array}
$$

Series $\hat{y}_{1}, \hat{y}_{2}, \hat{y}_{3}, \ldots, \hat{y}_{n}, \hat{y}_{n+1}$, is the input series into the model alignment exponentially-wavelet. By following the algorithm described in Section 3 of the model alignment exponentially-wavelet, we get the values: $\hat{\hat{y}}_{1}, \hat{\hat{y}}_{2}, \hat{\hat{y}}_{3}, \ldots, \hat{\hat{y}}_{n}$. With the solving of the task:

$$
\operatorname{Min}\left\{\sqrt{\frac{1}{n} \sum_{t=1}^{n}\left(\left(\alpha \hat{y}_{t}+(1-\alpha) y_{t-1}\right)-y_{t}\right)^{2}}\right\}
$$

on the assumption:

$$
\alpha \in\langle 0,1\rangle
$$

we get the expected number of unemployed eurozone countries in 2014 $\hat{\hat{y}}_{n+1}$, which according to the calculations copyright model is:

18 439,0 [in 100 persons] - with the extension sub-series Method $1^{2}$;

18 494,3 [in 100 persons] - with the extension sub-series Method 23 ;

18 566,7 [in 100 persons] - with the extension sub-series Method $3^{4}$.

The obtained values do not coincide with one hundred percent of the actual value, are subject to certain errors, which are listed in Table 1. From the proposed in the original model, the three ways of extending the sample during wavelet transform the most accurate prediction results, giving Method 1.

\footnotetext{
${ }^{2}$ Extension of polynomial samples (see: [Hadaś-Dyduch 2015b, 2015c]).

${ }^{3}$ The extension of the sample by symmetry.

${ }^{4}$ The extension of the sample by adding zeros.
} 
Table 1. Errors prediction

\begin{tabular}{|l|c|c|c|}
\hline \multirow{2}{*}{ Extension of sub-series } & \multicolumn{3}{|c|}{ Error } \\
\cline { 2 - 4 } & $\mathrm{AE}$ & $\mathrm{PE}$ & $\mathrm{APE}$ \\
\hline Method 1 & 9 & $0.00488 \%$ & $0.00488 \%$ \\
\hline Method 2 & 46.3393 & $-0.2512 \%$ & $0.2512 \%$ \\
\hline Method 3 & 118.6669 & $-0.6433 \%$ & $0.6433 \%$ \\
\hline
\end{tabular}

Source: own calculations based on the results of the research.

Table 2. Summary of errors prediction, the number of unemployed people in eurozone countries for 2014, depending on the method of prediction

\begin{tabular}{|c|r|r|r|}
\hline \multirow{2}{*}{ The method of prediction } & \multicolumn{3}{|c|}{ Error } \\
\cline { 2 - 4 } & \multicolumn{1}{|c|}{ AE } & \multicolumn{1}{c|}{ PE } & \multicolumn{1}{c|}{ APE } \\
\hline Naive method & 480.0000 & $-2.6019 \%$ & $2.6019 \%$ \\
\hline Exponential alignment for alpha: & & & \\
$1.0000^{*}$ & 1573.0000 & $-8.5267 \%$ & $8.5267 \%$ \\
0.9000 & 1521.7325 & $-8.2488 \%$ & $8.2488 \%$ \\
0.8000 & 1395.0456 & $-7.5620 \%$ & $7.5620 \%$ \\
0.1000 & 3545.0379 & $19.2164 \%$ & $19.2164 \%$ \\
0.0037 & 4339.4674 & $23.5227 \%$ & $23.5227 \%$ \\
0.0010 & 4330.2717 & $23.4729 \%$ & $23.4729 \%$ \\
0.0000 & 4326.0000 & $23.4497 \%$ & $23.4497 \%$ \\
\hline Trend method crawling with harmonics weights: & 1537.3791 & $-8.3336 \%$ & $8.3336 \%$ \\
\hline Method trend creep in combination with the & & & \\
method alignment the exponential. for alpha: & & & \\
$1.0000 *$ & 641.0000 & $-3.4746 \%$ & $3.4746 \%$ \\
0.9000 & 468.9078 & $-2.5418 \%$ & $2.5418 \%$ \\
0.8000 & 262.1223 & $-1.4209 \%$ & $1.4209 \%$ \\
0.5000 & 724.8076 & $3.9289 \%$ & $3.9289 \%$ \\
0.1000 & 4033.7839 & $21.8657 \%$ & $21.8657 \%$ \\
0.0500 & 4377.0371 & $23.7264 \%$ & $23.7264 \%$ \\
0.0037 & 4286.2678 & $23.2343 \%$ & $23.2343 \%$ \\
0.0010 & 4260.3434 & $23.0938 \%$ & $23.0938 \%$ \\
0.0000 & 4250.0000 & $23.0377 \%$ & $23.0377 \%$ \\
\hline
\end{tabular}

Source: own calculations based on the results of the research. 


\section{Conclusions}

The results of the prediction are acceptable. Prediction error, the proposed copyright model is low compared with other prediction methods (see Table 2). It should be noted that the prediction of the copyright line, i.e. the method of creeping trend, the exponential alignment method and wavelet analysis give better results than the same combination of the two methods but without wavelets (the method creeping trend with exponential alignment method - the author's suggestion).

The lowest error of the proposed alternative (similar) methods of prediction is fraught with the naive prediction method. However, this is just a coincidence. Because the errors of forecasts expired during the years 19972013 as determined by the naive are very large, i.e.: ME: 282.7059; MSE: 1,366,690.3529; RMSE: 1169.0553; nRMSE: 1017.5887; IEA: 877.8824; MAPE: 1536.1561\%; RMSPE: 2044.2497\%. Interesting results are also obtained from a combination of two methods of crawling the trend methods and methods alignment exponential (Table 2).

\section{References}

Albulescu C.T. (2010). Forecasting the Romanian financial system stability using a stochastic simulation model. Romanian Journal of Economic Forecasting 1(1). Pp. 81-98.

Andreica M. (2006). A model to forecast the evolution of the structure of a system of economic indicators. Romanian Journal of Economic Forecasting 3(1). Pp. 65-73.

Bruzda J. (2004). Wavelet vs. spectral analysis of an economic process. Dynamic Econometric Models 6. Pp.183-194.

Daubechies I. (1990). The wavelet transformation, time-frequency localization and signal analysis. IEEE Trans. Inform. Th. Vol. 36.

Dyduch M. (2010a). Prognozowanie kursu wymiany euro algorytmem z falka Daubechies. Prace Naukowe Uniwersytetu Ekonomicznego w Katowicach. Pp. 91-120.

Dyduch M. (2010b). Szacowanie wartości indeksu WIG-SPOZYW w przedziatach n-czasowych. Zeszyty Naukowe Uniwersytetu Szczecińskiego. Finanse. Rynki finansowe. Ubezpieczenia (29). Pp. 319-327.

Dyduch M. (2010c). Wspótczynniki transformaty falkowej jako narzędzie generujace prognozę przedziałowa szeregów czasowych. Prace Naukowe Uniwersytetu Ekonomicznego w Katowicach. Pp. 35-45.

Dyduch M. (2011). Prognozowanie szeregów czasowych w oparciu o współczynniki transformaty falkowej, optymalizowane przez sztuczna sieć neuronowa. Prace Naukowe Uniwersytetu Ekonomicznego w Katowicach. Pp. 59-69.

Dyduch M. (2013). Prognozowanie kursu wymiany euro z zastosowaniem transformaty falkowej. Prace Naukowe Uniwersytetu Ekonomicznego w Katowicach. Pp. 134-157. 
Haar A. (1910). Zur Theorie der orthogonalen Funktionen systeme. Mathematische Annalen 69(3). Pp. 331-371. doi:10.1007/BF01456326.

Hadaś-Dyduch M. (2013a). Efektywność inwestycji kapitałowych mierzona modelem opartym na analizie falkowej w niestabilnym otoczeniu gospodarczym. Studia Ekonomiczne 174. Pp. 307-313.

Hadaś-Dyduch M. (2013b). Prognozowanie szeregów czasowych w oparciu o wspólczynniki transformaty falkowej, optymalizowane przez sztuczna sieć neuronowa. [w:] Metody matematyczne, ekonometryczne i komputerowe w finansach i ubezpieczeniach 2011. Pp. 59-69.

Hadaś-Dyduch M. (2013c). Prognozowanie wskaźników makroekonomicznych z uwzględnieniem transformaty falkowej na przykladzie wskaźnika inflacji. Zeszyty Naukowe Wyższej Szkoły Bankowej we Wrocławiu 2. Pp. 175-186.

Hadaś-Dyduch M. (2013d). Wykorzystanie metod analizy falkowej do mierzenia efektywności polisy inwestycyjnej. Wiadomości Ubezpieczeniowe 1. Pp. 37-48.

Hadaś-Dyduch M. (2014a). Non-classical algorithm for time series prediction of the range of economic phenomena with regard to the interaction of financial market indicators. Chinese Business Review 13(4). David Publishing Company. New York.

Hadaś-Dyduch M. (2014b). Wplyw rozszerzenia próbki przy generowaniu wspólczynników falkowych szeregu na trafność prognozy. Ekonometria. Wydawnictwo Uniwersytetu Ekonomicznego we Wrocławiu. Vol. 4. Issue 46. Pp. 62-71.

Hadaś-Dyduch M. (2015a). Polish macroeconomic indicators correlated-prediction with indicators of selected countries. In: M. Papież, S. Śmiech (eds.). Proceedings of the $9^{\text {th }}$ Professor Aleksander Zelias International Conference on Modelling and Forecasting of Socio-Economic Phenomena. Conference Proceedings. Foundation of the Cracow University of Economics. Cracow.

Hadaś-Dyduch M. (2015b). Prognozy instrumentów finansowych generowane współczynnikami falkowymi z rozszerzeniem. Studia Ekonomiczne 227. Pp. 5-15.

Hadaś-Dyduch M. (2015c). Wavelets in Prediction. Theory, Method, Simulation. Scholars' Press.

Horodko L. (2001). Wplyw typu falki na wtasności czasowo-częstotliwościowej reprezentacji niestacjonarnego sygnału. Zeszyty Naukowe. Elektryka. Politechnika Łódzka. No. (98). Pp. 287-294.

Joo T.W., Kim S.B. (2015). Time series forecasting based on wavelet filtering. Expert Systems with Applications 42(8). Pp. 3868-3874.

Nievergelt Y. (1999). Wavelets Made Easy. Vol. 174. Birkhäuser. Boston, Mass, USA: 